\title{
Development of Mamestra brassicae and its solitary endoparasitoid Microplitis mediator on two populations of the invasive weed Bunias orientalis
}

\author{
Jeffrey A. Harvey $\cdot$ Rieta Gols
}

Received: 5 August 2010/Accepted: 17 March 2011/Published online: 9 April 2011

(C) The Author(s) 2011. This article is published with open access at Springerlink.com

\begin{abstract}
The warty cabbage Bunias orientalis is an invasive pest in much of central Europe, including much of Germany since the 1980s, whereas in other countries, such as The Netherlands, it is a less common exotic species. Here, healthy larvae of Mamestra brassicae, which has been found feeding on B. orientalis plants in Germany, and larvae parasitized by one of its major larval endoparasitoids Microplitis mediator, were reared on both herbivoreinduced and noninduced leaves of $B$. orientalis originating from single large populations growing in The Netherlands and central Germany. Herbivore performance was less negatively affected than parasitoid performance by differences in plant quality. Development times in both M. brassicae and Mi. mediator were shorter on Dutch than German plants and also shorter on noninduced than induced plants. Moreover, survival and body size of the parasitoid was more strongly affected by plant population and induction than survival of healthy $M$. brassicae. Chemical analyses of defensive secondary metabolites [glucosinolates (GS)] revealed that concentrations of the major GS sinalbin were constitutively expressed in German plants whereas they were induced in Dutch plants. However, in separate feeding bioassays in which preference for induced and noninduced leaves was compared separately,
\end{abstract}

\footnotetext{
J. A. Harvey $(\bowtie)$

Department of Terrestrial Ecology,

Netherlands Institute of Ecology, Droevendaalsesteeg 10, 6708 PB Wageningen, The Netherlands

e-mail: j.harvey@nioo.knaw.nl

R. Gols

Department of Entomology, Wageningen University, PO Box 8031, 6700 EH Wageningen, The Netherlands
}

L3 instars of M. brassicae preferred noninduced German plants over Dutch plants but induced Dutch plants over German plants, revealing that changes in primary metabolites or an unidentified non-GS compound mediates population-related differences in plant quality. The results reveal asymmetric effects of plant quality in exotic plants on organisms in the second and third trophic level.

Keywords Allelochemical · Host quality - Invasive plants $\cdot$ Multitrophic interactions $\cdot$ Parasitoid

\section{Introduction}

Consequences of the establishment and spread of exotic, invasive plants into nonnative ecosystems has received considerable attention in recent years (Booth et al. 2010). When they enter new habitats, invasive plants may interact with native insects with which they may have no evolutionary history. Given that they occur at the basal end of the food chain, invasive plants have the capacity to seriously disrupt existing food webs, including multitrophic interactions involving insect herbivores and their natural enemies (Cronin and Haynes 2004; Harvey et al. 2010b). Thus far, virtually all studies with invasive plants and native insects have been restricted to interactions between the first trophic level (the plant) and potential enemies (e.g., insect herbivores) in the second trophic level (hence, the term enemy has strictly been applied to herbivores and not carnivores). On the other hand, interactions between exotic plants, native herbivores, and their natural enemies in higher trophic levels, such as parasitoids or predators, have been generally ignored. In a groundbreaking paper, Price et al. (1980) argued that, in addition to bi-trophic interactions involving plants and herbivores, a better 
understanding of the factors that influence community structure and function should include carnivores in the third trophic level.

Plant quality, mediated in part by defensive allelochemistry, has long been known to negatively affect the performance of herbivorous insects through increased mortality or a reduction in adult size and growth rate (Rosenthal and Berenbaum 1992; Schoonhoven et al. 2005). It has also been reported that parasitoids in the third trophic level may also be affected by the quality of the food plant as mediated through the herbivore host (Harvey 2005; Ode 2006). These effects can be positive or negative. For instance, several studies have reported that the internal immune defences of herbivores are traded off against detoxification when these herbivores feed on more toxic plant species or genotypes, making these herbivores more susceptible to endoparasitoids (Bukovinszky et al. 2009; Smilanich et al. 2009). Alternatively, the growth, survival, and fitness of parasitoids may be affected by plant toxins ingested by the host (Barbosa et al. 1986, 1991; Harvey 2005; Harvey et al. 2005; Ode 2006; Gols et al. 2008). These effects may be direct, e.g., through exposure of parasitoid larvae to allelochemicals stored in host tissues; or indirect, e.g., when the host itself performs badly on certain diets. Plant quality has also been shown to trickle up to affect organisms, such as hyperparasitoids, in the fourth trophic level (Harvey et al. 2003, 2007; Morse 2009).

In this study, we examined a tri-trophic interaction involving an exotic plant, the warty cabbage Bunias orientalis L. (Capparales: Brassicaceae); the cabbage moth, Mamestra brassicae L. (Lepidoptera: Noctuidae); and its solitary endoparasitoid, Microplitis mediator Haliday (Hymenoptera: Braconidae). Bunias orientalis is native to western Asia but was widely introduced to many parts of central and western Europe in the nineteenth century (Dietz et al. 1996, 1999). During the 1980s, however, it began a simultaneous explosion in abundance and rapidly became a dominant invasive part of the flora in many countries, including Germany, Czech Republic, Poland, Sweden, Norway, and elsewhere (Harvey et al. 2010a). At the same time, though established, it is not yet an invasive pest in several neighboring countries, including France, Great Britain, and The Netherlands. A cursory survey of herbivores on B. orientalis in eastern Germany in 2006 revealed that the only insect herbivore to be frequently observed was M. brassicae. In lab studies, Harvey et al. (2010a) also found that several specialist and generalist herbivores performed very poorly on $B$. orientalis, with the exception of $M$. brassicae, which enjoyed high fitness on this plant.

We compared survival, development time, and adult body mass in $M$. brassicae and Mi. mediator when developing on $B$. orientalis plants obtained from single populations in Jena, Germany, where it is exceedingly abundant, and near Wageningen, The Netherlands, where it is less common. As with many other species in the large family Brassicaceae, B. orientalis produces inducible glycoside toxins known as glucosinolates (GS). GS and their breakdown products are known to negatively affect the development of insect herbivores, pathogens, and nematodes (Potter et al. 1999; Li et al. 2000; Buskov et al. 2002). Levels of allelochemicals often increase in response to herbivory, with potentially negative consequences for consecutive attackers (Karban and Baldwin 1997; Agrawal 1999). We compare the development of the insects on plants from the two populations that were damaged several days earlier by $M$. brassicae versus plants that had not been damaged (controls). Last, we compare the development of the host and parasitoid on excised leaves of $B$. orientalis collected from the field versus leaves of a cabbage (Brassica oleracea) cultivar on which the herbivore has a long rearing history. Our main hypotheses are: (1) that there are insignificant differences in quality between the two $B$. orientalis populations, (2) that there will be a strong link between herbivore and parasitoid performance, (3) that both species perform worse on induced than on noninduced plants, and (4) that the cabbage cultivar will be of higher quality than $B$. orientalis for the host and its parasitoid.

\section{Methods and materials}

Using Dutch and German accessions, all experiments with plants and insects were performed in climate rooms at $25 \pm 2{ }^{\circ} \mathrm{C}$ with a $16: 8$-h light:dark photoperiod.

Plants

Bunias orientalis (Fig. 1a) is a perennial plant that may live up to 10 years or even longer. The seeds germinate in autumn, with new rosettes produced the following year that consist of up to hundreds of leaves. Furthermore, the roots of parent plants may produce horizontal stems below ground, which produce spatially extensive networks of interconnected, yet functionally autonomous, plants. Plants typically begin to flower in early May and produce fruits that are ripe by midsummer.

Seeds of $B$. orientalis were obtained from an established wild population growing along a railway line midway between Arnhem and Nijmegen, The Netherlands, within a few hundred meters of the Rhine River. Plants from this population originated from a small cluster of $\sim 20$ plants. Seeds from a German population were collected from $\sim 20$ plants growing in a field adjacent to 

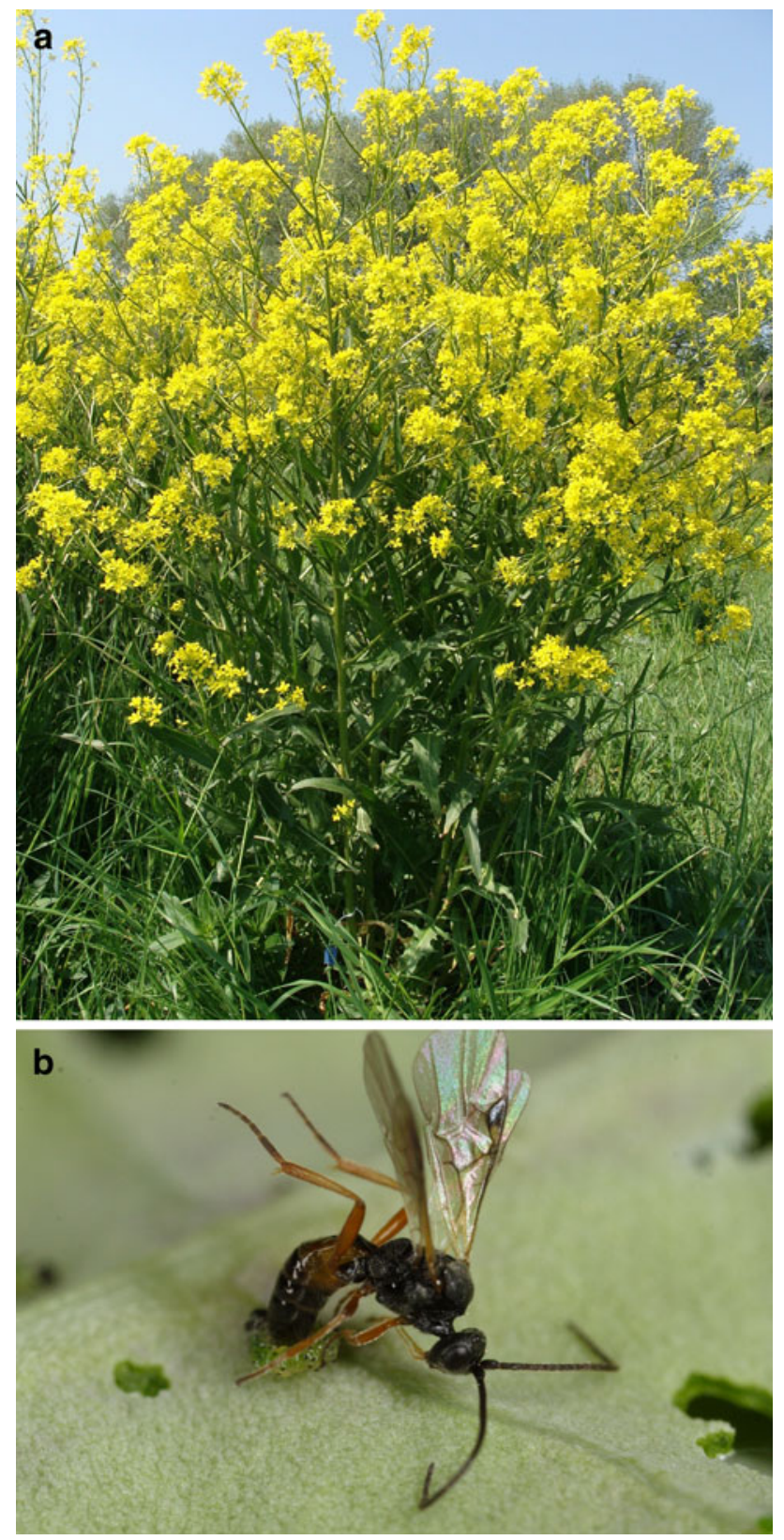

Fig. 1 a Fully grown Bunias orientalis plant growing near to Wageningen, The Netherlands, and $\mathbf{b}$ adult female of the parasitoid Microplitis mediator ovipositing into second instar larva of Mamestra brassicae

the Max Planck Institute for Chemical Ecology in Jena. Bunias orientalis grows in the city in disturbed areas such as road sides and abandoned fields. The seeds of $B$. orientalis were extracted from dried fruits by gently cracking them open using a nutcracker and were allowed to germinate in small plastic boxes $(15 \times 10 \times 6 \mathrm{~cm})$ containing glass beads immersed in tap water. Newly germinated seedlings were grown in 2-1 plastic pots containing a soil mixture consisting of approximately 30\% sand, 5\% clay, and $65 \%$ peat. Plants were grown in a greenhouse at $22 \pm 2^{\circ} \mathrm{C}, 50-70 \%$ r.h, with a photoperiod of at least $16 \mathrm{~h}$. Natural daylight was supplemented by metal-halide lamps $\left(225 \mu \mathrm{mol}\right.$ photons $\left./ \mathrm{m}^{2} / \mathrm{s}\right)$ during the 16 -h photoperiod. Plants were watered daily, and after 2 weeks, they were provided with nutrient-enhanced Hoagland solution to compensate for nutrient depletion in the soil. All plants used in the development and preference assays were between 4 and 5 weeks old. In addition, Brussels sprout plants ( $\mathrm{Br}$. oleracea var. gemmifera $\mathrm{cv}$. Cyrus) were grown from seeds under the same conditions as the $B$. orientalis plants.

To induce $B$. orientalis plants, six first instar M. brassicae larvae (two larvae per leaf) were allowed to feed on the plants for 5 days, after which time larvae were removed. Pieces of tissue from the herbivore-damaged leaves were used in the development studies (see below). Induced plants were prepared every 2 days.

Insects

Larvae of M. brassicae were obtained from the Department of Entomology, Wageningen University, where they had been reared for many years on Brussels sprout (cv. Cyrus) plants. Mamestra brassicae is native to the Palearctic realm, is considered to be a generalist herbivore, and is very frequently a pest in cabbage and other crops. Larvae were originally collected in cabbage fields near Wageningen University. Newly emerged moths were placed in groups of 20 into plastic containers $(12 \times 20 \mathrm{~cm})$ with $10 \%$ sugar solution absorbed into cotton wool in small plastic vials. Filter paper was placed into the containers and as a cover, and the moths laid their eggs onto this substrate. Every day, the filter paper was removed and stored pending hatching. New filter paper was placed inside and over the containers. Mi. mediator (Fig. 1b) was collected from young $M$. brassicae caterpillars on potted cabbage plants that had been placed for a week into a flowering meadow adjacent to the Laboratory of Entomology at Wageningen University. The parasitoid is also native to Eurasia and develops in first (L1) to third (L3) larval instars of its hosts, into which female wasps oviposit a single egg. This parasitoid is a specialist species of moths in the family Noctuidae. In Europe, M. brassicae is considered to be its primary host.

Several hundred newly hatched L1 caterpillars were placed onto cabbage plants in a rearing cage $(40 \times 40 \times$ $60 \mathrm{~cm}$ ) and allowed to feed. After $24 \mathrm{~h}, 60$ wasps $>5$ days (about half of each sex) were released into the cage and allowed to parasitize larvae for several days. Sugar solution was constantly provided, and new plants were supplied as necessary for larval development. Larvae were allowed to develop until parasitoid egression and pupation. Cocoons 
of Mi. mediator were collected from cages and placed in large Petri dishes $(15 \mathrm{~cm}$ in diameter) until parasitoid eclosion.

\section{Development of Mamestra brassicae and Microplitis mediator on Bunias orientalis}

\section{Healthy hosts}

Egg batches of $M$. brassicae were allowed to hatch on the filter paper. Neonate larvae were then randomly allocated to $9.5-\mathrm{cm}$ Petri dishes (seven larvae per dish) with excised middle-aged leaves from one of the four plant treatments: German control (noninduced), German induced, Dutch control or Dutch induced B. orientalis (ten dishes per treatment). A disc of moistened filter paper was inside each dish to prevent leaf tissues from desiccating. Every 2 days, leaf materials and filter paper were replaced and larval mortality was recorded. Healthy larvae grow much larger than parasitized larvae. Therefore, healthy larvae from each Petri dish were transferred to larger plastic containers $(15 \times 10 \times 10 \mathrm{~cm})$ when they were in the fourth larval instar. Mature larvae normally burrow into the soil to pupate; here, mature L5 larvae were provided with a layer of vermiculite approximately $3 \mathrm{~cm}$ deep in plastic boxes for this purpose. Prepupae that had stopped feeding and were in the vermiculite were carefully checked every day to determine when they had pupated. Fresh pupae were removed and weighed on an analytic balance (accuracy $+0.1 \mathrm{mg})$. The larval development time was determined as the number of days between hatching and pupation.

\section{Parasitized hosts}

Newly molted L2 caterpillars that had been feeding on either control or induced excised leaf tissues from the two $B$. orientalis populations were individually presented to mated female $M$. mediator wasps on the end of a brush in small plastic vials. Parasitism was verified by a single insertion and removal of the ovipositor. Parasitized caterpillars were placed into $9.5-\mathrm{cm}$ Petri dishes (ten caterpillars per dish, ten dishes per treatment) lined with moistened filter paper and provided with excised leaves from the same treatment group as they had been feeding on previously. Every 2 days, leaf materials and the filter paper were replaced, and larval mortality was recorded. Parasitized hosts grow only to a small fraction of the size of healthy hosts, and wasps typically egress and pupate after 8-9 days. Newly emerged adult wasps were sexed, narcotized using carbon dioxide $\left(\mathrm{CO}_{2}\right)$, and weighed on the microbalance. Parasitoid eclosion was checked several times over the course of $24 \mathrm{~h}$. Development time (in hours) was determined as the duration between parasitism and adult emergence.

Development of Mamestra brassicae and Microplitis mediator on Brassica oleracea and Bunias orientalis

In an additional experiment, the performance of $M$. brassicae and Mi. mediator was compared on the Br. olerace a cultivar, on which both species were reared for many generations, and on leaf tissues collected from $B$. orientalis plants that grew outside in a field plot. It was expected that both species would perform better on the cabbage cultivar than on $B$. orientalis. The protocol for this experiment was the same as described above for both healthy and parasitized caterpillars.

Glucosinolate analyses of leaf tissues from noninduced and induced Bunias orientalis plants

To compare the quality and quantity of foliar GS in B. orientalis plants from the two populations, leaf tissues were collected from undamaged control plants and plants that had been induced by $M$. brassicae feeding for 5 days as described in "Plants". The distal parts (approximately $20 \mathrm{~cm}^{2}$ ) were cut from all fully developed leaves of a plant individual, pooled, and immediately stored in paper bags at $-20^{\circ} \mathrm{C}$. Eight samples were collected from each plant species for both treatments (damaged and control). Undamaged and damaged plants were of the same age and were sampled on the same day. Samples were freeze-dried and pulverized. GS were extracted from $40 \mathrm{mg}$ of ground leaf material in boiling $70 \%$ methanol. The extract was purified and desulfated on a DEAE-Sephadex A26 column. The desulfated GS were separated on a reverse-phase C-18 column (Alltima C-18, $3 \mu \mathrm{m}, 150 \times 4.6 \mathrm{~mm}$, Alltech, Deerfield, IL, USA) by high-performance liquid chromatography (HPLC) (Dionex, Sunnyvale, CA, USA) with an acetonitrile water gradient. Detection was performed with a Dionex PDA-100 Photodiode array detector set to scan from 200 to $350 \mathrm{~nm}$. For quantification, sinigrin (Sigma, St. Louis, IL, USA) was used as an external standard. Peaks were integrated at $229 \mathrm{~nm}$, for which standard response factors have been defined. The different GS were identified based on their retention times and ultraviolet (UV) spectra compared with the pure compounds, sinalbin (Sigma, St. Louis, IL, USA), or compared with a certified oil seed reference (EC Community).

Plant preference of Mamestra brassicae for induced and noninduced leaf tissues

Bunias orientalis plants from the Dutch and German population were grown as for the insect development experiments. The process of induction was also the same. Leaf 
discs $(2 \mathrm{~cm}$ in diameter) from induced and noninduced plants were taken from plants from the two populations. Two discs from each population were placed on opposite sides on damp filter paper in a Petri dish ( $15 \mathrm{~cm}$ in diameter). A single L3 caterpillar of $M$. brassicae that had been previously reared on cabbage was then introduced into the dish and allowed to feed for the following $15 \mathrm{~h}$ and then removed. Induced $(n=10)$ and noninduced $(n=20)$ plants were compared separately. The damage of excised leaves was determined using a computer scanner (Model Epsom 4990).

\section{Statistical analyses}

To investigate the effect of the two populations (Dutch or German) and plant treatment (induced or not) on the performance (development time and biomass) of healthy M. brassicae and its parasitoid Mi. mediator, we used a general linear model analysis of variance (ANOVA). In addition to plant population and treatment, we included sex as an explanatory variable in the analysis of parasitoid performance data. Data on individual insects were the experimental units in each analysis. Post hoc Tukey-Kramer analyses were performed when the ANOVA models were significant. Development time data were log-transformed to meet assumptions of normality and homoscedacity. Glucosinolate concentrations were also analyzed using a general linear model ANOVA, with plant population and treatment as explanatory variables. Concentrations measured in individual plants were the experimental units in this analysis. Data on 4-methylsulfinilbutyl GS were logtransformed before they were subjected to the analysis.

Data on survival of healthy M. brassicae and its parasitoid Mi. mediator were analyzed using nonparametric KaplanMeier survival curves (Kleinbaum 1996). Larvae that had pupated (healthy $M$. brassicae) or hosts from which parasitoid larvae had egressed were censored. The log-rank test was used to compare survival curves on the different treatments, and a sequential Bonferroni correction was applied to adjust $\alpha$ for type I error. Data on consumption in the preference study were compared using paired $t$ tests.

\section{Results}

Development of Mamestra brassicae and Microplitis mediator on Bunias orientalis

\section{Healthy M. brassicae}

Population $\left(F_{1,141}=79.4, \quad P<0.001\right)$ and treatment $\left(F_{1,141}=30.2, P<0.001\right)$ had a significant effect on larva-to-pupa development of healthy caterpillars. M. brassicae developed faster on Dutch than on German
$B$. orientalis and faster on noninduced than on induced plant tissues (Fig. 2a). Only the population $\times$ treatment interaction $\left(F_{1,141}=5.15, P=0.03\right)$ significantly affected pupal mass; pupal mass was lower on induced than on noninduced German plant tissues, whereas induction had no effect on pupal mass when the caterpillars had been feeding on Dutch B. orientalis (Fig. 2b).

\section{Parasitoid}

Development time of the parasitoid (Fig. 2c) also depended on host-plant population $\left(F_{1,195}=45.4, P<0.001\right)$ and whether or not the plants had been induced $\left(F_{1,195}=25.4\right.$, $P<0.001)$. As was found for healthy caterpillars, $M i$. mediator developed faster on Dutch than on German $B$. orientalis and on noninduced than on induced plant tissues. However, the population $\times$ treatment interaction term was also significant $\left(F_{1,195}=16.3, P<0.001\right)$; the difference in development time on induced and noninduced plants was larger on German than on Dutch B. orientalis. Population $\left(F_{1,195}=4.44, P=0.04\right)$, treatment $\left(F_{1,195}=\right.$ $34.4, P<0.001)$, and sex $\left(F_{1,195}=5.40, P=0.02\right)$ significantly affected adult fresh mass of parasitoids (Fig. 2d). Male wasps were heavier than females and, irrespective of their sex, wasps weighed more when the host had been feeding on Dutch plant tissues. Moreover, induction of the host's food negatively affected adult dry mass of the parasitoid, resulting in lower adult masses on induced than on noninduced plant tissues.

\section{Development of Mamestra brassicae and Microplitis} mediator on Brassica oleracea and Bunias orientalis

Healthy $M$. brassicae developed significantly faster on $B r$. oleracea than on $B$. orientalis $\left(F_{1,122}=270\right.$, $P<0.001$, Fig. 3a), whereas pupal mass was not affected $\left(F_{1,121}=1.10, P=0.30\right.$, Fig. $\left.3 b\right)$. Moth pupae were actually marginally heavier on $B$. orientalis plants. In contrast, plant species had no effect on development time of the parasitoid $\left(F_{1,115}=1.02, P=0.32\right.$, Fig. $\left.3 c\right)$ but did affect adult biomass $\left(F_{1,120}=73.5, P<0.001\right.$, Fig. $\left.3 \mathrm{~d}\right)$; parasitoids were significantly heavier when the host had been feeding on $\mathrm{Br}$. oleracea compared with $B$. orientalis plants. Males developed significantly faster $\left(F_{1,115}=22.7\right.$, $P<0.001)$ and were significantly heavier than females $\left(F_{1,20}=23.9, P<0.001\right)$ irrespective of the plant species on which the host had been feeding.

Survival of Mamestra brassicae and Microplitis mediator

Survival to pupation of $M$. brassicae was not significantly different on the two populations irrespective of plant 

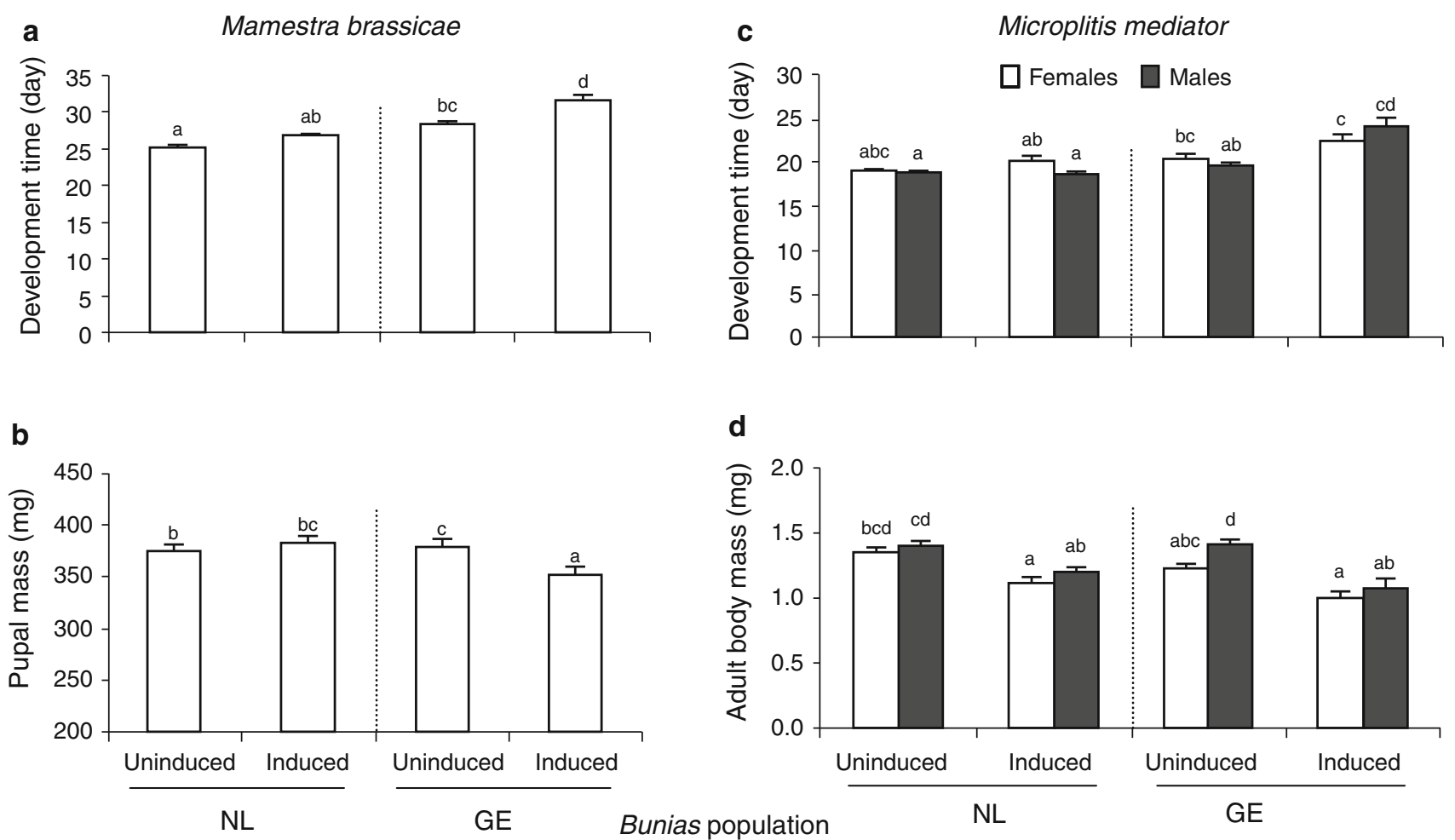

Fig. 2 Developmental parameters of $\mathbf{a}, \mathbf{b}$ Mamestra brassicae and its parasitoid, c, d Microplitis mediator on noninduced and herbivoreinduced plants of Bunias orientalis originating from two populations in Germany and The Netherlands. a Egg-to-pupal development time in $M$. brassicae in days; b pupal mass of $M$. brassicae in milligrams;

treatment (log-rank test $\chi^{2}=7.4, \quad d f=3, \quad P=0.06$; Fig. 4a). In contrast, survival to pupation of the parasitoids was significantly affected by plant population and treatment (log-rank test $\chi^{2}=34.0, d f=3, P<0.001$; Fig. 4b). On both plant populations, more wasps survived on noninduced than on induced leaf tissues (log-rank test: Germany, $\chi^{2}=20.8, d f=1, P<0.001$; Dutch, $\chi^{2}=8.8$, $d f=1, P=0.003$ ). In addition, more wasps survived to pupation on the Dutch than on the German induced plants $\left(\chi^{2}=5.5, d f=1, P=0.019\right)$, whereas survival was similar on both plant populations for the noninduced treatment $\left(\chi^{2}=0.005, d f=1, P=0.94\right)$.

Plant preference of Mamestra brassicae for induced and noninduced plants

Third instar $M$. brassicae larvae consumed significantly more German than Dutch noninduced leaf tissues $\left(t_{19}=2.12, \quad P=0.048 ;\right.$ Fig. 5). However, when the plants had previously been exposed to $M$. brassicae feeding, new $M$. brassicae caterpillars consumed more of the Dutch than the German leaf tissues $\left(t_{9}=2.34\right.$, $P=0.044 ;$ Fig. 5). c egg-to-adult development time of Mi. mediator in days; $\mathbf{d}$ adult body mass in Mi. mediator in milligrams. Line bars represent standard error of the mean. Bars with different letters are significantly different (Tukey-Kramer tests for multiple comparisons among means with $\alpha=0.05)$

Glucosinolate analyses of leaf tissues from noninduced and induced Bunias orientalis plants

Three different GS compounds were found in leaf tissues of B. orientalis (Fig. 6), of which sinalbin was the major constituent (85-95\% of total GS content). Total GS concentrations were similar in the two populations (for statistics, see Table 1) and tended to be higher in induced plants, but this was not significant $(P=0.051)$. Levels of sinalbin were significantly lower and levels of 4-methylsulfinylbut-3-enyl GS significantly higher in leaf tissues of the Dutch than in the German plants, whereas concentrations of these two GS were unaffected by herbivore induction. Concentrations of 4-methylsulfinylbutyl GS were similar in the two populations and were not affected by induction.

\section{Discussion}

In this study, we found decidedly asymmetrical effects of plant quality in $B$. orientalis on development and survival of the cabbage moth, M. brassicae, and its parasitoid, Mi. mediator. Moreover, these effects were to some extent 

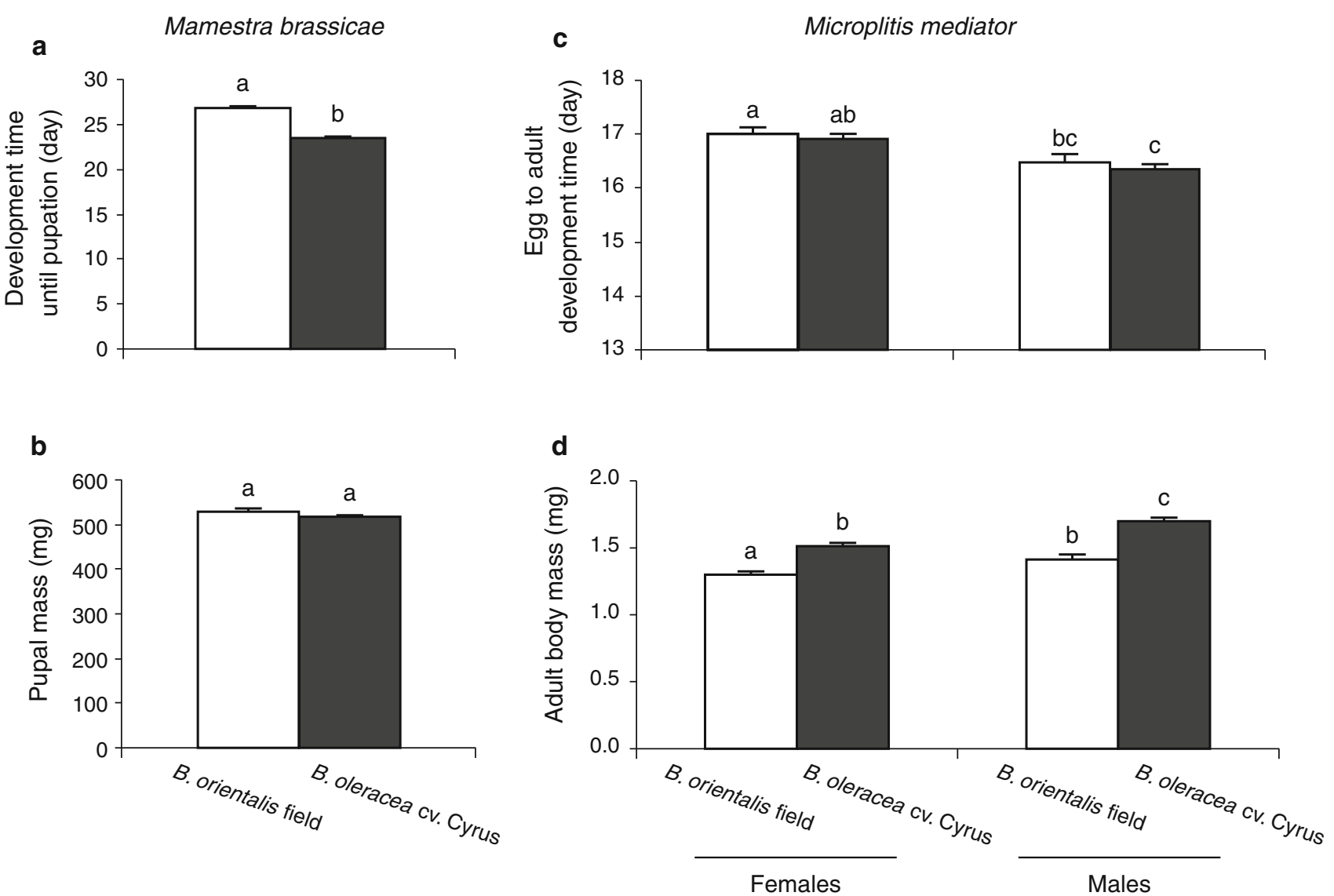

Fig. 3 Developmental parameters of a, b Mamestra brassicae and its parasitoid, c, d Microplitis mediator on a Brussels sprout cultivar (Brassica oleracea cv. Cyrus) (grey bars) and field-grown Bunias

M. brassicae in days; b pupal mass of $M$. brassicae in milligrams; c egg-to-adult development time of Mi. mediator in days; $\mathbf{d}$ adult body mass in Mi. mediator in milligrams. Line bars represent standard error of the mean. Bars with different letters are significantly different $(P<0.05)$

a

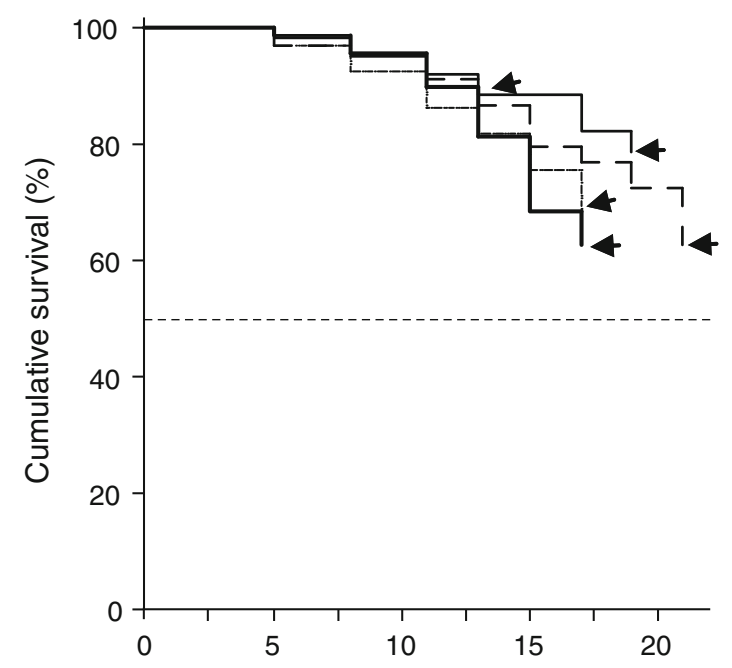

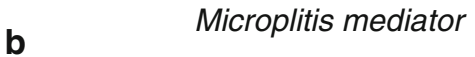

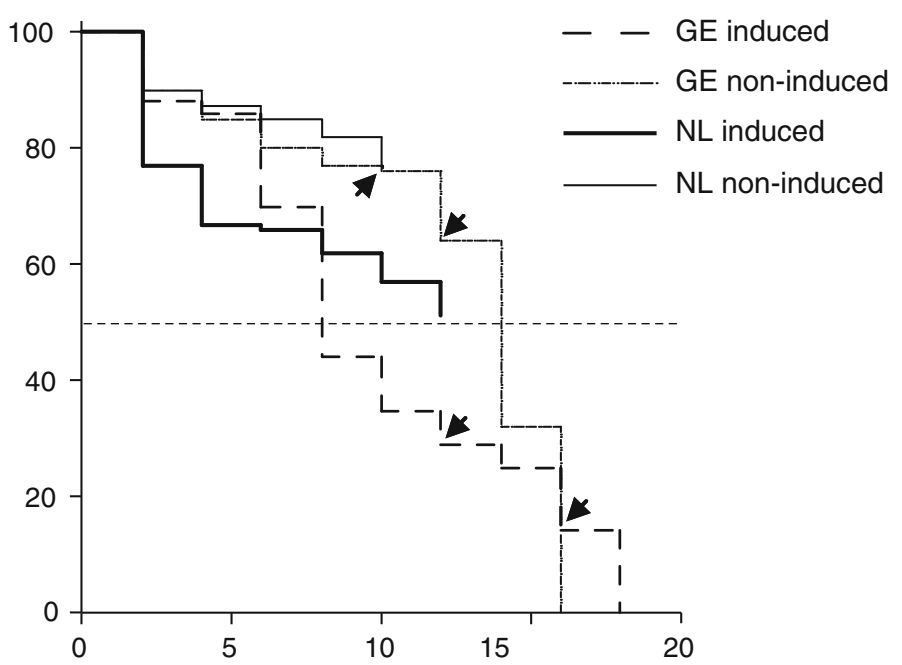

Survival time (day)

Fig. 4 Cumulative survival tendencies (percent) of a Mamestra brassicae larvae and $\mathbf{b}$ Microplitis mediator when reared on detached leaves from noninduced and herbivore-induced plants of Bunias orientalis originating from a population in Germany and The Netherlands. Arrows indicate when healthy caterpillars had pupated or parasitoids had expressed from the host, and the analysis was adjusted accordingly 


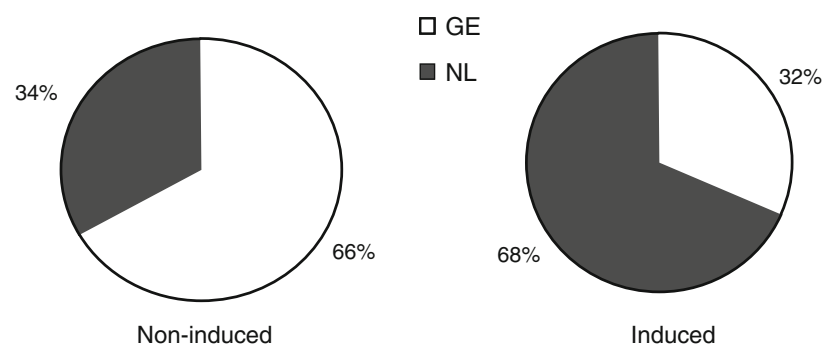

Fig. 5 Percentage of damage inflicted over $14 \mathrm{~h}$ by L3 larvae of Mamestra brassicae feeding on noninduced and herbivore-induced plants of Bunias orientalis originating from two populations in Germany and The Netherlands. Sample sizes were 20 and 10 for noninduced and induced comparisons, respectively

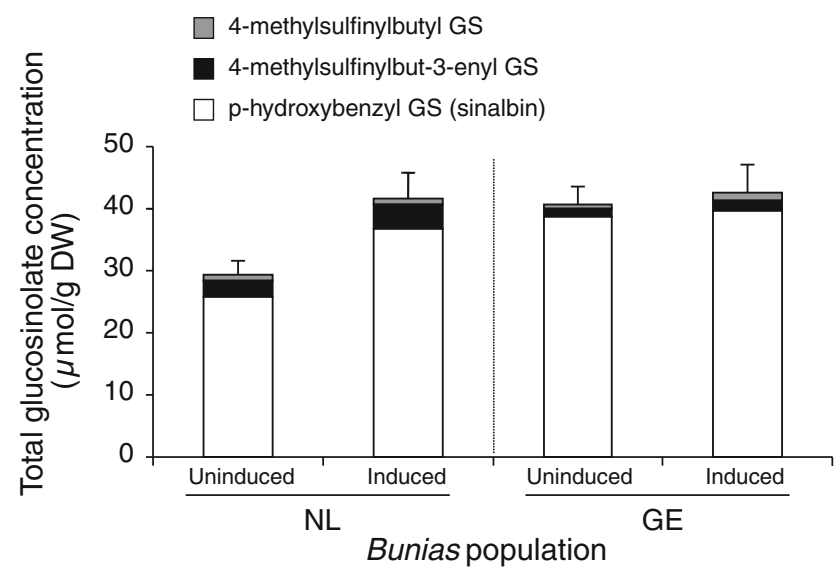

Fig. 6 Glucosinolate (GS) concentrations in leaf tissues from plants of which seeds had been collected in The Netherlands (NL) and Germany (GE). GS were measured in leaf tissues of undamaged control (noninduced) plants and in leaf tissues from plants that had been exposed to Mamestra brassicae feeding for 5 days (induced plants). The sample size was eight per population per treatment

amplified by herbivore damage of plant tissues and differed between the German and Dutch populations of this weed. Although herbivore survival did not differ between the two populations of $B$. orientalis and was similar on control and induced plants, there were divergent population-related effects on other fitness correlates. Development time was extended on German plants and on plants that had been induced by $M$. brassicae. In contrast, parasitoid survival was significantly lower on German than Dutch plants irrespective of their treatment, and adult wasps were smaller on induced plants. Development time of the parasitoid was more strongly affected by induction on the German than on the Dutch plants.

These results show that plant-quality effects on herbivore performance can have disproportionate effects further up the food chain. As with many other endoparasitoids, the developmental program of $\mathrm{Mi}$. mediator is expected to be well integrated with that of its host (Pennacchio and Strand 2006). Endoparasitoid larvae often use physiological cues, such as hemolymph protein concentrations or levels of juvenile hormone titers inside the host to determine at which rate to grow and at what point to begin destructive feeding pending egression (Beckage 2004). In this way, the growth rate of parasitoid immatures, as well as development time and size, is often closely tailored to the growth of the host. However, the profound divergence in the survival of $M$. brassicae and $M i$. mediator on induced and noninduced plants reveals that something in the host diet is more negatively affecting the parasitoid than it is the host. In other associations, food-plant quality affects the host more dramatically than its parasitoid, presumably because the herbivore must detoxify or excrete plant allelochemicals, which are then diluted up the food chain (Barbosa et al. 1986; Ode 2006; Harvey et al. 2007). Interestingly, although $M$. brassicae developed with equal success on a cabbage cultivar with which it has a rearing history and Dutch field-collected $B$. orientalis, again, parasitoids were smaller when developing on hosts reared on $B$. orientalis.

Herbivore preference for Dutch and German B. orientalis plants changed dramatically in response to plant induction. German plants were preferred before induction whereas after induction, this position was reversed. In the context of GS production, results are difficult to interpret and suggest that some other factor(s) is important in determining plant quality. The primary GS present in shoots of B. orientalis is $p$-hydroxy benzyl, otherwise known as sinalbin. Concentrations of this GS greatly increased in leaf tissues of Dutch $B$. orientalis plants following herbivore damage but not in German B. orientalis plants. Furthermore, sinalbin is the dominant glucosinolate found in shoots of other crucifers, including the charlock mustard Sinapis arvensis, which is native to all of Eurasia and is abundant in The Netherlands. Further complicating matters, Harvey et al. (2010a) found that levels of sinalbin are lower in leaves of $S$. arvensis than in leaves of $B$. orientalis. Despite this, M. brassicae performed much more successfully on $B$. orientalis than on $S$. arvensis. This contrasts with specialist herbivores, including the cabbage butterflies Pieris rapae and $P$. brassicae, where $B$. orientalis is fairly toxic and $S$. arvensis highly suitable (Harvey et al. 2010a). It is likely that non-GS allelochemicals present in German B. orientalis and S. arvensis plants account for the differential effects on the performance of specialist and generalist herbivores. A recent study (Kühnle and Müller 2009) found that the beetle Phaedon cochleariae, which is a specialist on brassicaceous plants, performed more poorly on an invasive population of $B$. orientalis than on native crucifers. The authors isolated a flavonoid in $B$. orientalis that acted as a feeding deterrent in adult beetles. However, it remains to be determined exactly what factors are responsible for the effects described in this study.

When an exotic plant enters a new community, novel interactions with native insects are likely to occur. The outcomes of these novel interactions are difficult to predict 
Table 1 Statistical analysis of glucosinolate (GS) concentrations in leaf tissues of noninduced and induced German and Dutch Bunias orientalis

\begin{tabular}{llcc}
\hline GS & Explanatory variable & $F(d f=1,28)$ & $P$ value \\
\hline Total & Population & 3.22 & 0.08 \\
& Treatment & 4.14 & 0.05 \\
& Population $\times$ treatment & 2.32 & 0.14 \\
$p$-Hydroxybenzyl GS (sinalbin) & Population & 27.1 & $<0.001$ \\
& Treatment & 0.29 & 0.59 \\
& Population $\times$ treatment & 0.57 & 0.46 \\
4-Methylsulfinylbutyl GS & Population & 0.32 & 0.58 \\
& Treatment & 2.69 & 0.11 \\
& Population $\times$ treatment & 0.46 & 0.5 \\
4-Methylsulfinylbut-3-enyl GS & Population & 16.6 & $<0.001$ \\
& Treatment & 1.88 & 0.18 \\
& Population $\times$ treatment & 0.88 & 0.35 \\
\hline
\end{tabular}

because the exotic plant brings with it traits that evolved elsewhere. These traits might make the plant toxic to native herbivores, or conversely, it may be highly palatable (Agosta 2006; Agosta and Klemens 2008). Clearly, there is an element of chance, although it appears that plants that are phylogenetically and chemically unique in their new habitats are more likely to be avoided by native herbivores (Louda et al. 1997; Cappuccino and Arnason 2006; Müller 2009). In studies conducted in New England, USA, Keeler et al. (2006) and Keeler and Chew (2008) examined interactions between the highly invasive garlic mustard, Alliaria petiolata, which is native to Eurasia, and native specialist herbivores, including the mustard white butterfly, Pieris oleracea. Leaves of $A$. petiolata contain allelochemicals, including alliarinoside and cyanide, which are toxic to caterpillars of $P$. oleracea with which it has presumably not coevolved (Cappuccino and Arnason 2006; Cipollini and Gruner 2007). The effects of these toxins on natural parasitoids of $P$. oleracea have not been studied, but given that this butterfly has declined regionally in concert with an increase in the abundance of $A$. petiolata over the past century, there is a strong likelihood that its specialized natural enemies-most importantly, endoparasitoids-have suffered as well. Further research will determine whether this is indeed the case.

Studies involving the effects of exotic plants on communities in the invaded range have been the focus of considerable attention over the past two decades (Sakai et al. 2001). Despite this, research has almost exclusively focused on bitrophic interactions involving plants and herbivores (Louda et al. 1997; Keane and Crawley 2002; Parker et al. 2006). The potential importance of top-down control of herbivores by natural enemies has been demonstrated many times in classic biological control programs in agroecosystems (Mills 2001). In many natural ecosystems, it has been argued that herbivores are controlled by a combination of bottom-up (plant-mediated) and top-down (natural-enemy-mediated) forces (Hunter and Price 1992; Schmitz et al. 2000). Consequently, the disproportionate effect of exotic plants on native species in the second or third trophic levels has the potential of amplifying or, alternatively, countering the effects of bottom-up processes. This can occur through the disruption of hostfinding or dispersal efficiency of herbivores and their parasitoids (Cronin and Haynes 2004; Heleno et al. 2009) or else through stronger effects of plant quality being mediated on one party or the other (this study; see also review by Harvey et al. 2010b). It is hoped that future studies will combine ecological and physiological approaches in examining multitrophic interactions involving exotic plants, herbivores, and their natural enemies. The results of such studies will shed more light on the possible factors that facilitate the ability of a few plant species to become invasive pests whereas most do not.

Acknowledgments We thank Gregor Disveld for providing experimental facilities and André Gidding for supplying eggs of Mamestra brassicae. Michael Reichelt of the Max Planck Institute in Jena, Germany, kindly analyzed the GS. Hans Smid is thanked for his help with the figures. Taiadjana Fortuna supplied the photograph of Bunias orientalis, and Tibor Bukovinszky (http://www.bugsinthepicture.com/) kindly supplied the photograph of Mi. mediator parasitizing M. brassicae.

Open Access This article is distributed under the terms of the Creative Commons Attribution Noncommercial License which permits any noncommercial use, distribution, and reproduction in any medium, provided the original author(s) and source are credited.

\section{References}

Agosta SJ (2006) On ecological fitting, plant-insect associations, herbivore host shifts, and host plant selection. Oikos 114:556-565

Agosta SA, Klemens JA (2008) Ecological fitting by phenotypically flexible genotypes: implications for species associations, community assembly and evolution. Ecol Lett 11:1123-1134 
Agrawal AA (1999) Induced responses to herbivory in wild radish: effects on several herbivores and plant fitness. Ecology 870:1713-1733

Barbosa P, Saunders JA, Kemper R, Trumbule J, Olechno J, Martinat $P$ (1986) Plant allelochemicals and insect parasitoids: effects of nicotine on Cotesia congregata and Hyposoter annulipes. J Chem Ecol 12:1319-1328

Barbosa P, Gross P, Kemper J (1991) Influence of plant allelochemicals on the performance of the tobacco hornworm and its parasitoid, Cotesia congregata. Ecology 72:1567-1575

Beckage NE (2004) Wasp parasitoid disruption of host development: implications for new biologically based strategies for insect control. Annu Rev Entomol 49:299-330

Booth BD, Murphy SD, Swanton CJ (2010) Invasive plant ecology in natural and agricultural systems. CABI Biosciences, Oxford

Bukovinszky T, Poelman EH, Gols R, Prekatsakis G, Vet LEM, Harvey JA, Dicke M (2009) Consequences of constitutive and induced variation in plant nutritional quality for immune defence of a herbivore against parasitism. Oecologia 160:299-308

Buskov S, Serra B, Rosa E, Sorensen H, Sorensen JC (2002) Effects of intact glucosinolates and products produced from glucosinolates in myrosinase-catalyzed hydrolysis on the potato cyst nematode (Globodera rostochiensis cv. Woll). J Agric Food Chem 50:690-695

Cappuccino N, Arnason JT (2006) Novel chemistry of exotic plants. Biol Lett 2:189-193

Cipollini D, Gruner B (2007) Cyanide in the chemical arsenal of garlic mustard, Alliaria petiolata. J Chem Ecol 33:85-94

Cronin JT, Haynes KJ (2004) Invasive plants promote unstable hostparasitoid patch dynamics. Ecology 85:2772-2782

Dietz H, Steinlein T, Winterhalter P, Ullmann I (1996) Role of allelopathy as a possible factor associated with the rising dominance of Bunias orientalis L. (Brassicaceae) in some native plant assemblages. J Chem Ecol 22:1797-1811

Dietz H, Steinlein T, Ullmann I (1999) Establishment of the invasive perennial herb Bunias orientalis L.: an experimental approach. Acta Oecol 20:621-632

Gols R, Bukovinszky T, van Dam NM, Bullock JM, Dicke M, Harvey JA (2008) Genetic variation in the defense chemistry of wild cabbage populations and its effects on native herbivores and their endoparasitoids. Ecology 89:1616-1626

Harvey JA (2005) Factors affecting the evolution of development strategies in parasitoid wasps: the importance of functional constraints and incorporating complexity. Entomol Exp Appl 117:1-13

Harvey JA, van Dam NM, Gols R (2003) Interactions over four trophic levels: foodplant quality affects development of a hyperparasitoid as mediated through a herbivore and its primary parasitoid. J Anim Ecol 72:520-531

Harvey JA, van Nouhuys S, Biere A (2005) Effects of quantitative variation in allelochemicals in Plantago lanceolata on development of a generalist and a specialist herbivore and their endoparasitoids. J Chem Ecol 31:287-302

Harvey JA, van Dam NM, Witjes LMA, Soler R, Gols R (2007) Effects of dietary nicotine on the development of a herbivore, its parasitoid and secondary hyperparasitoid over four trophic levels. Ecol Entomol 32:15-23

Harvey JA, Biere A, Fortuna T, Vet LEM, Engelkes T, Morriën E, Gols R, Verhoeven K, Vogel H, Macel M, Heidel-Fisher H, Schramm K, van der Putten WH (2010a) Ecological fits, misfits and lotteries involving insect herbivores on the invasive plant, Bunias orientalis. Biol Invasions 12:3045-3059

Harvey JA, Bukovinszky T, van der Putten WH (2010b) Interactions between invasive plants and insect herbivores: a plea for a multitrophic perspective. Biol Conserv 143:2251-2259
Heleno RH, Ceia RS, Ramos JA, Memmott J (2009) Effects of alien plants on insect abundance and biomass: a food-web approach. Conserv Biol 23:410-419

Hunter MD, Price PW (1992) Playing chutes and ladders: heterogeneity and the relative roles of bottom-up and top-down forces in natural communities. Ecology 73:724-732

Karban R, Baldwin IT (1997) Induced responses to herbivory. University of Chicago Press, Chicago

Keane RM, Crawley MJ (2002) Exotic plant invasions and the enemy release hypothesis. Trends Ecol Evol 17:164-170

Keeler MS, Chew FS (2008) Escaping an evolutionary trap: preference and performance of a native insect on an exotic host. Oecologia 156:559-568

Keeler MS, Chew FS, Goodale BC, Reed JM (2006) Modelling the impacts of two exotic species on a native butterfly: top-down vs. bottom-up effects. J Anim Ecol 75:777-788

Kleinbaum DG (1996) Survival analysis: a self-learning text. Springer, New York

Kühnle A, Müller C (2009) Differing acceptance of familiar and unfamiliar plant species by an oligophagous beetle. Entomol Exp Appl 131:189-199

Li Q, Eigenbrode SD, Stringham GR, Thiagarajah MR (2000) Feeding and growth of Plutella xylostella and Spodoptera eridania on Brassica juncea with varying glucosinolate concentrations and myrosinase activities. J Chem Ecol 26:2401-2419

Louda SM, Kendall D, Connor J, Simberloff D (1997) Ecological effects of an insect introduced for the biological control of weeds. Science 277:1088-1090

Mills NJ (2001) Factors influencing top-down control of insect pest populations in biological control systems. Basic Appl Ecol $2: 323-332$

Morse DH (2009) Four-level interactions: herbivore use of ferns and subsequent parasitoid-hyperparasitoid performance. Ecol Entomol 34:246-253

Müller C (2009) Role of glucosinolates in plant invasiveness. Phytochem Rev 8:227-242

Ode PJ (2006) Plant chemistry and natural enemy fitness: effects on herbivore and natural enemy interactions. Annu Rev Entomol 51:163-185

Parker JD, Burkepile DE, Hay ME (2006) Opposing effects of native and exotic herbivores on plant invasions. Science 311:1459-1461

Pennacchio F, Strand MR (2006) Evolution of developmental strategies in parasitic Hymenoptera. Annu Rev Entomol 51:233-258

Potter MJ, Vanstone VA, Davies KA, Kirkegaard JA, Rathjen AJ (1999) Reduced susceptibility of Brassica napus to Pratylenchus neglectus in plants with elevated root levels of 2-phenylethyl glucosinolate. J Nematol 31:291-298

Price PW, Bouton CE, Gross P, McPheron BA, Thompson JN, Weis $\mathrm{AE}$ (1980) Interactions among three trophic levels: influence of plants on interactions between insect herbivores and natural enemies. Annu Rev Ecol System 11:41-65

Rosenthal GA, Berenbaum MR (1992) Herbivores: their interactions with secondary plant metabolites. Academic Press, San Diego

Sakai AK, Allendorf FW, Holt JS, Lodge DM, Molofsky J, Baughman S, Cabin RJ, Cohen JE, Ellstrand NC, McCauley DE, O'Neil P, Parker IM, Thompson JN, Weller SG (2001) The population biology of exotic species. Annu Rev Ecol System $32: 305-332$

Schmitz OJ, Hamback PA, Beckerman AP (2000) Trophic cascades in terrestrial systems: a review of the effects of carnivore removals on plants. Am Nat 155:141-153

Schoonhoven LM, van Loon JJA, Dicke M (2005) Insect-plant biology, 2nd edn. Oxford University Press, Oxford

Smilanich AM, Dyer LA, Chambers JQ, Bowers MD (2009) Immunological cost of chemical defence and the evolution of herbivore diet breadth. Ecol Lett 12:612-621 